\title{
Pengaruh Profitabilitas dan Leverage Pada Earning Response Coefficient Dengan Ukuran Perusahaan Sebagai Variabel Pemoderasi
}

\author{
Nyoman Sutrisna Dewi ${ }^{1}$ \\ I Ketut Yadnyana ${ }^{2}$ \\ ${ }^{1,2}$ Fakultas Ekonomi dan Bisnis Universitas Udayana (Unud), Bali, Indonesia \\ e-mail: sutrisnadewi1104@gmail.com
}

\begin{abstract}
ABSTRAK
Penelitian ini dilakukan pada perusahaan manufaktur yang terdaftar di Bursa Efek Indonesia periode 2015-2017. Sampel yang diperoleh sejumlah 58 perusahaan dengan 174 amatan. Penentuan sampel menggunakan metode non probability sampling dengan teknik purposive sampling. Teknik analisis data yang digunakan adalah uji Moderated Regression Analysis. Berdasarkan hasil penelitian ini ditemukan bahwa profitabilitas dan leverage berpengaruh negatif pada ERC. Semakin tinggi perusahaan menghasilkan keuntungan dan semakin tinggi tingkat leverage yang dimiliki maka semakin rendah nilai ERC perusahaan. Ditemukan hasil bahwa ukuran Perusahaan mampu memperlemah pengaruh profitabilitas pada ERC dan ukuran perusahaan memperkuat pengaruh leverage pada ERC.

Kata kunci: Profitabilitas, leverage, ukuran perusahaan, earning response coefficient
\end{abstract}

\begin{abstract}
This research was conducted at manufacturing companies listed on the Indonesia Stock Exchange for the period 2015-2017. The sample obtained was 58 companies with 174 observations. Determination of the sample using non probability sampling method with purposive sampling technique. The data analysis technique used is the Moderated Regression Analysis test. Based on the results of this study it was found that profitability and leverage had a negative effect on the ERC. The higher the company makes a profit and the higher the leverage level it has, the lower the ERC value of the company. It was found that Company size can weaken the influence of profitability on the ERC and company size can strengthened the influence of leverage on the ERC.

Keywords: Profitability, leverage, company size, earnings response coefficient
\end{abstract}

\section{PENDAHULUAN}

Laporan keuangan merupakan suatu bentuk pertanggungjawaban manajemen perusahaan mengenai aktivitas bisnisnya kepada publik yang dituangkan dalam informasi keuangan. Dalam laporan keuangan terkandung berbagai macam informasi yang diperlukan oleh pengguna laporan sebagai dasar pertimbangan untuk mengambil keputusan ekonomi. Laporan laba rugi merupakan salah satu komponen dalam laporan keuangan yang menjadi perhatian utama investor dan 
selalu ditunggu-tunggu informasinya. Hal ini disebabkan karena laporan laba rugi menggambarkan keberhasilan atau kegagalan perusahaan dalam menjalankan bisnisnya.

Penelitian Agustianto (2013) menyatakan bahwa laba menjadi salah satu faktor penting dalam menaksir kinerja dan sebagai informasi dasar bagi investor dalam melakukan penaksiran laba. Melalui laba, investor maupun kreditur dapat menilai kinerja manajemen, memprediksi risiko dalam berinvestasi dan mampu memprediksi laba yang akan diperoleh di masa mendatang. Informasi laba memegang peranan penting dalam mengukur perubahan bersih atas kekayaan pemegang saham serta merupakan indikasi kemampuan perusahaan dalam menghasilkan laba.

Teori sinyal menjelaskan bahwa perusahaan memiliki dorongan untuk menyampaikan informasi yang dimiliki kep ada publik guna meminimalisir asimetri informasi. Informasi laba merupakan sinyal positif berupa good news dimana perusahaan selalu ingin melaporkan informasi tersebut kepada publik dengan harapan pasar akan segera bereaksi sesaat setelah pengumuman laba disampaikan. Laba yang dihasilkan perusahaan akan mempengaruhi respon pasar dan pergerakan harga saham.

Investor tentu merasa senang apabila perusahaan mengumumkan laba yang tinggi karena investor akan mendapatkan dividen atas tiap kepemilikan saham yang dimiliki (Adriani, 2012). Dengan tingkat laba yang tinggi berarti perusahaan memberikan sinyal berupa good news kepada publik agar minat investor dalam berinvestasi semakin tinggi. Mengingat pentingnya informasi laba 
bagi para investor, manajer selaku pengelola perusahaan diharapkan mampu memberikan informasi yang sesungguhnya dan tidak menyesatkan. Namun tidak sedikit manajemen yang melakukan berbagai kecurangan seperti manipulasi laporan keuangan karena sikap investor yang cenderung mengukur kinerja manajemen melalui laba yang dihasilkan perusahaan.

Kecurangan yang dilakukan oleh perusahaan pada laporan keuangannya tentu dapat menurunkan bahkan menghilangkan kepercayaan dari investor terhadap kualitas laba. Sudarma dan Ratnadi (2015) menyatakan bahwa laba akuntansi yang berkualitas adalah laba yang mempunyai sedikit atau tidak mengandung gangguan persepsian (perceived noise) didalamnya dan dapat mencerminkan kinerja keuangan perusahaan yang sebenarnya. Dari penelitian tersebut, dapat disimpulkan bahwa laba yang berkualitas adalah laba yang dapat menyebabkan bergeraknya reaksi pasar lebih tinggi dan mampu mempengaruhi respon investor dalam membuat keputusan.

Reaksi pasar tergantung dari kualitas laba yang dihasilkan perusahaan dan kualitas laba tidak berhubungan dengan tinggi atau rendahnya laba yang dilaporkan perusahaan kepada publik. Oleh karena laba dapat mempengaruhi keputusan ekonomi yang dibuat para pengguna laporan keuangan maka laba dikatakan memiliki kandungan informasi. Namun, laba memiliki keterbatasan yang dipengaruhi oleh asumsi perhitungan dan juga kemungkinan manipulasi yang dilakukan oleh manajemen perusahaan sehingga dibutuhkan informasi lain selain laba untuk memprediksi return saham perusahaan yaitu koefisien respon laba atau disebut juga dengan Earning Response Coefficient (Tahir, 2016). 
Sebagai informasi yang menjadi perhatian utama investor dalam mengambil keputusan maka kualitas laba perlu diukur.

Berdasarkan teori Earning Response Coefficient (ERC) merupakan suatu koefisien yang berhubungan dengan informasi yang terdapat pada laba akuntansi dan menjadi ukuran sensitivitas perubahan harga saham terhadap laba akuntansi. ERC menunjukkan reaksi pasar terhadap informasi laba yang dipublikasikan oleh perusahaan yang dapat diamati dari pergerakan harga saham disekitar tanggal publikasi laporan keuangan (Natalia dan Ratnadi, 2017). Menurut Cheng dan Nasir (2010) ERC merupakan estimasi perubahan harga saham perusahaan akibat dari informasi laba perusahaan yang diumumkan ke pasar. Setiap perusahaan memiliki nilai ERC yang berbeda tergantung dari bagaimana informasi laba yang dilaporkan mampu mempengaruhi respon investor dan pergerakan harga saham perusahaan. Tabel 1 menyajikan data mengenai pergerakan harga saham perusahaan di sekitar tanggal publikasi laporan keuangan.

Tabel 1.

Pergerakan Harga Saham Perusahaan Manufaktur

\begin{tabular}{lcccccc}
\hline \multicolumn{1}{c}{ Kode } & Tanggal Publikasi & T-2 & T-1 & T0 & T+1 & T+2 \\
\hline GGRM & 28 Maret 2018 & 70,300 & 70,700 & 70,900 & 72,475 & 73,400 \\
INTP & 22 Maret 2018 & 18,950 & 18,725 & 17,625 & 16,475 & 16,000 \\
STTP & 26 Juni 2018 & 3,800 & 3,800 & 3,800 & 3,800 & 3,800 \\
\hline Sumber: Data diolah, 2018 & & & & &
\end{tabular}

Berdasarkan Tabel 1 dapat dilihat bahwa terdapat perbedaan pada pergerakan harga saham di sekitar event window setiap perusahaannya. Hal ini disebabkan karena investor memiliki persepsi dan ekspetasi yang berbeda-beda dalam menanggapi informasi laba yang telah dilaporkan perusahaan. Secara teoritis, volume dan harga saham segera berubah setelah perusahaan mempublikasikan laporan keuangannya (Subagyo dan Olivia, 2012). 
Jauh sebelum perusahaan menerbitkan laporan keuangan, pasar telah mempunyai ekspektasi mengenai berapa besar laba yang dihasilkan perusahaan. Pada saat laba aktual diumumkan dan terdapat selisih maka disebut sebagai laba kejutan (unexpected earning). Scott (2009:145) menyatakan apabila laba aktual lebih besar dari laba ekspetasi maka hal ini akan menjadi good news yang dapat menyebabkan investor memutuskan untuk membeli saham perusahaan. Sebaliknya jika laba aktual lebih kecil dari laba ekspetasi maka akan menjadi bad news dan dapat mengakibatkan investor untuk segera menjual saham perusahaan.

Penelitian pertama mengenai laba dilakukan oleh Ball dan Brown (1958) yang menguji tentang kandungan informasi unexpected earning. Unexpected earning direpresentasi oleh reaksi pasar yang diukur dengan abnormal return. Abnormal return merupakan selisih dari return yang sesungguhnya terjadi terhadap return normal atau return ekspetasi. Abnormal return akan bernilai positif jika investor memperoleh good news yang tercermin dari adanya unexpected earning positif. Sedangkan abnormal return akan bernilai negatif jika investor memperoleh bad news yang ditunjukkan dari adanya unexpected earning negatif.

Semakin tinggi tingkat kredibilitas dari informasi yang dipublikasikan dan informasi telah mampu menunjukkan kondisi yang sebenarnya terjadi di perusahaan akan memperkuat respon pasar. Kekuatan reaksi tersebut tercermin dalam nilai ERC yang tinggi. Tingginya nilai ERC mencerminkan bahwa laba mampu menjadi informasi yang memiliki relevansi nilai sehingga membantu investor dalam membuat keputusan. Sebaliknya, respon pasar dan nilai ERC akan 
menjadi rendah bila laporan keuangan dirasa kurang informatif dan masih diragukan kualitasnya.

Terdapat banyak faktor yang dapat mempengaruhi kualitas laba yang diukur dengan menggunakan ERC seperti yang telah diteliti oleh Fitri (2013), Setiawati, dkk. (2014), Nurdiyah (2015) dan Herdirinandasari dan Asyik (2016) yaitu persistensi laba, struktur modal, risiko sistematik (beta), kesempatan bertumbuh, ukuran perusahaan, kualitas auditor, leverage, likuiditas, ukuran KAP dan voluntary disclosure. Penelitian ini menggunakan profitabilitas dan leverage sebagai variabel independen.

Pemilihan profitabilitas dalam penelitian ini karena profitabilitas merupakan salah satu indikator keberhasilan perusahaan untuk dapat menghasilkan laba serta tingkat profitabilitas menjadi basis yang penting bagi perusahaan maupun investor. Dalam hal membuat keputusan, respon investor akan dipengaruhi oleh efektivitas kinerja perusahaan ini yang terefleksi dari informasi laba yang dilaporkan. Perusahaan yang mampu mengoperasikan aktiva yang dimiliki untuk memaksimalkan labanya akan lebih cepat direspon oleh pasar dan berdampak positif terhadap ERC. Penelitian Hayn (1995) menyimpulkan bahwa ERC pada perusahaan yang mengalami kerugian umumnya lebih kecil daripada ERC perusahaan yang menghasilkan laba. Berdasarkan hasil penelitian yang dilakukan Setiawati dkk. (2014), Mahendra dan Wirama (2017) dan Herdirinandasari dan Asyik (2016) yang menyimpulkan bahwa profitabilitas berpengaruh terhadap ERC. Namun penelitian Rullyan (2017), Fitri (2013) dan 
Nurdiyah (2015) menemukan bahwa profitabilitas perusahaan tidak berpengaruh terhadap ERC.

Struktur permodalan perusahaan juga berpengaruh terhadap ERC. Struktur modal dalam penelitian ini diproksikan dengan leverage. Leverage menunjukkan seberapa besar perusahaan bergantung pada pendanaan yang berasal dari utang untuk membiayai kegiatan operasi bisnisnya. Semakin tinggi tingkat leverage suatu perusahaan akan menimbulkan rendahnya respon pasar dan dapat berdampak negatif pada nilai ERC. Hal ini dikarenakan jika perusahaan yang memiliki tingkat leverage tinggi melaporkan adanya laba, maka perusahaan akan lebih mendahulukan pembayaran utang kepada kreditur daripada pembagian deviden kepada investor sehingga respon investor akan menjadi negatif. Penelitian yang dilakukan Nofianti (2014), Dewi dan Putra (2017) membuktikan bahwa leverage berpengaruh negatif terhadap ERC. Sementara hasil penelitian Delvira dan Nelvirita (2013), Nurdiyah (2015) dan Hasanzade et al. (2013) menyimpulkan bahwa leverage tidak berpengaruh signifikan terhadap ERC.

Penelitian ini merupakan replikasi dari gabungan beberapa penelitian sebelumnya. Namun hasil yang tidak konsisten dari penelitian sebelumnya mengenai pengaruh profitabilitas dan leverage terhadap ERC dapat dipengaruhi oleh adanya variabel lain. Oleh karena itu penelitian ini mencoba memasukkan satu variabel moderasi yang digunakan untuk memperkuat atau memperlemah pengaruh antara variabel profitabilitas dan leverage dengan ERC. Ukuran perusahaan digunakan sebagai variabel moderasi dalam penelitian dengan asumsi bahwa perusahaan besar mampu untuk meningkatkan kualitas labanya melalui 
peningkatan kinerja manajemen sehingga investor cenderung lebih percaya pada perusahaan besar.

Penelitian Farizky (2012) menunjukkan bahwa terdapat pengaruh positif antara ukuran perusahaan dan ERC. Perusahaan berukuran besar biasanya memiliki total aktiva yang besar. Besarnya total aktiva yang dimiliki menyebabkan usaha perusahaan untuk mengembangkan bisnisnya melalui berbagai inovasi baru akan lebih mudah dilakukan sehingga laba yang dihasilkan perusahaan dapat mengalami peningkatan. Kenaikan tingkat laba akan memberikan respon positif terhadap kinerja manajemen dan tentunya dapat berdampak pada tingginya nilai ERC. Selain itu, perusahaan berukuran besar biasanya membutuhkan dana yang lebih banyak untuk menjalankan kegiatan bisnisnya. Tidak sedikit perusahaan menggunakan dana yang bersumber dari kreditur dalam mengoperasikan perusahaan. Oleh karena itu perusahaan berukuran besar cenderung lebih mudah memperoleh pinjaman dana dari kreditur karena adanya jaminan pembayaran dimasa mendatang dengan total aset yang lebih besar.

Penelitian ini memilih lokasi penelitian yaitu seluruh perusahaan manufaktur yang terdaftar di Bursa Efek Indonesia (BEI) pada periode 20152017. Perusahaan manufaktur digunakan sebagai sampel karena perusahaan manufaktur merupakan jenis usaha dengan jumlah perusahaan paling banyak dibandingkan jenis usaha lain serta lebih diminati oleh investor untuk dijadikan tempat berinvestasi. 
Lev (1989) mengartikan profitabilitas sebagai kemampuan perusahaan untuk menghasilkan laba atau profit dalam upaya meningkatkan nilai pemegang saham. Semakin tinggi profitabilitas yang dimiliki perusahaan berarti semakin tinggi pula kemampuan perusahaan dalam menghasilkan laba. Perusahaan yang memiliki profitabilitas tinggi dapat dikatakan bahwa laporan keuangannya mengandung berita baik sebagai suatu hasil dari adanya kinerja perusahaan yang baik. Laba perusahaan dikatakan berkualitas hanya jika keuntungan perusahaan meningkat (Hejazi et al. 2015). Dalam teori sinyal dijelaskan bahwa perusahaan akan melaporkan seluruh informasi yang dimiliki sebagai sinyal perusahaan kepada publik dan untuk meminimalisir adanya asimetri informasi.

Sinyal positif berupa laba merupakan good news yang selalu diharapkan investor dari perusahaan tempat mereka berinvestasi. Ketika perusahaan mengumumkan adanya laba maka investor cenderung merespon informasi tersebut dengan cepat karena laba dianggap menguntungkan dalam pembagian deviden. Oleh karena itu, semakin tinggi profitabilitas maka akan semakin besar respon investor sehingga perusahaan akan berusaha untuk menghasilkan laba yang tinggi guna meningkatkan harga saham dan nilai pemegang saham.

Besarnya respon investor dalam menanggapi laba juga akan berdampak pada tingginya nilai ERC suatu perusahaan. Setiawati dkk. (2014), Mahendra dan Wirama (2017), Herdirinandasari dan Asyik (2016) dan Hasanzade et al. (2013) melakukan penelitian dan membuktikan adanya pengaruh positif antara profitabilitas dan ERC. Namun hasil berbeda didapat dalam penelitian Anggraini (2015) dan Pitria (2017) yang menyatakan profitabilitas berpengaruh negatif 
terhadap reaksi investor yang berarti nilai ERC perusahaan menjadi rendah. Berdasarkan penelitian-penelitian tersebut hipotesis yang dapat dikembangkan adalah :

$\mathrm{H}_{1}$ : Profitabilitas berpengaruh positif pada Earning Response Coefficient.

Resiko gagal bayar perusahaan biasanya dilihat dari tinggi rendahnya leverage yang dimiliki. Leverage merupakan alat untuk mengukur seberapa jauh suatu perusahaan bergantung pada pendanaan yang berasal dari utang dalam membiayai aset perusahaan. Penggunaan utang biasanya bertujuan untuk membantu perusahaan dalam mengembangkan kegiatan produksinya dengan begitu perusahaan dapat menghasilkan laba yang lebih besar. Bagi investor, semakin besar laba yang dihasilkan berarti memperbesar tingkat pengembalian yang akan diterima pemiliknya. Oleh karena itu secara tidak langsung penggunaan utang dapat memperbesar laba perusahaan yang berarti memakmurkan pemegang sahamnya.

Perusahaan dengan leverage yang tinggi mengindikasikan bahwa perusahaan menggunakan lebih banyak utang daripada modal yang dimiliki. Semakin tinggi tingkat leverage maka semakin berat beban keuangan yang dihadapi perusahaan sehingga memiliki tingkat risiko yang tinggi pula. Tingginya tingkat risiko mencerminkan adanya kemungkinan bahwa perusahaan tersebut tidak bisa melunasi kewajiban atau utangnya baik berupa pokok ataupun bunganya. Oleh karena itu, respon investor cenderung rendah untuk perusahaan dengan tingkat leverage yang tinggi karena investor kurang percaya terhadap laba yang dipublikasikan perusahaan dan mengakibatkan investor takut untuk 
berinvestasi di perusahaan tersebut. Investor beranggapan bahwa ketika perusahaan mengumumkan adanya laba maka laba akan dialokasikan terlebih dahulu untuk membayar utangnya kepada kreditur daripada membagikan deviden. Lemahnya respon investor akibat tingginya leverage tentu dapat menurunkan Earning Response Coefficient pada perusahaan yang bersangkutan. Hasil penelitian Nofianti (2014), Dewi dan Putra (2017), Dhaliwal et al. (1991), Moradi et al. (2010), dan An (2015) membuktikan bahwa leverage berpengaruh negatif terhadap ERC. Namun penelitian Valipour dan Moradbeygi (2011) menemukan hasil yang berbeda yaitu adanya hubungan positif antara leverage dan kualitas laba. Berdasarkan penelitian-penelitian tersebut, hipotesis yang dapat dikembangkan adalah :

$\mathrm{H}_{2}$ : Leverage berpengaruh negatif pada Earning Response Coefficient.

Ukuran perusahaan dapat dilihat melalui jumlah total aset yang dimiliki oleh perusahaan. Perusahaan yang memiliki total aktiva besar akan lebih mudah untuk menjalankan aktivitas bisnisnya serta melakukan inovasi baru dalam usahanya untuk mengembangkan kegiatan bisnisnya. Banyaknya inovasi baru yang dilakukan perusahaan menunjukkan semakin baik kinerja perusahaan sehingga memungkinkan bagi perusahaan untuk menghasilkan laba yang tinggi (Rahayu dan Suaryana, 2015). Peningkatan laba yang tercermin dalam peningkatan profitabilitas dapat meningkatkan harga saham perusahaan dan secara tidak langsung akan turut mempengaruhi respon pasar.

Menurut Mahendra dan Wirama (2017) perusahaan dengan ukuran besar relatif lebih stabil dan lebih mampu menghasilkan laba dibanding dengan 
perusahaan kecil serta dianggap mampu untuk terus meningkatkan kinerja perusahaannya sehingga akan meningkatkan kualitas labanya. Hal ini tentu menyebabkan investor lebih tertarik untuk menanamkan modalnya pada perusahaan yang mampu menghasilkan laba. Oleh karena itu, perusahaan berukuran besar yang cenderung dapat menghasilkan laba yang tinggi akan mendapat respon positif dari investor. Semakin besar ukuran perusahaan maka berdampak pada tingginya nilai ERC karena perusahaan besar memiliki risiko kebangkrutan yang lebih kecil dibandingkan dengan perusahaan kecil (Mashayekhi dan Aghel, 2016). Dengan demikian, semakin besar ukuran perusahaan maka semakin baik kualitas laba yang dimiliki (Malahayati dkk. 2015). Berdasarkan uraian di atas, hipotesis yang dapat dikembangkan adalah :

$\mathrm{H}_{3}$ : Ukuran perusahaan dapat memperkuat pengaruh profitabilitas pada Earning Response Coefficient

Utang adalah salah satu sumber pendanaan yang berasal dari pihak eksternal guna membantu perusahaan dalam menjalankan bisnisnya. Leverage menurut Dewi dan Putra (2017) merupakan penggunaan sumber dana yang memiliki beban tetap, dengan harapan akan memberikan tambahan keuntungan yang lebih besar dari pada beban tetap, sehingga keuntungan pemegang saham bertambah. Penggunaan utang diyakini dapat menunjang kegiatan produksi sehingga diharapkan dapat meningkatkan nilai perusahaan yang tercermin pada harga pasar sahamnya sampai batas tertertu. Namun setelah batas tersebut tercapai maka penambahan utang akan menurunkan nilai perusahaan karena manfaat dari penggunaan utang lebih kecil dari biaya yang harus ditanggung perusahaan. Jika perusahaan tidak mampu menutupi utang yang telah jatuh tempo dengan laba 
yang dihasilkan maka akan berpengaruh besar bagi investor saat mengambil keputusan.

Pada umumnya perusahaan besar membutuhkan dana yang lebih banyak untuk menjalankan operasi perusahaan dan meningkatkan produksinya. Tidak sedikit perusahaan yang menggunakan utang dalam membiayai aset perusahaan. Perusahaan berukuran besar cenderung lebih mudah memperoleh dana dari pihak eksternal berupa utang karena adanya jaminan pembayaran dimasa mendatang dengan total aset yang lebih besar. Dengan demikian semakin besar perusahaan maka semakin tinggi tingkat leveragenya dan respon investor akan menjadi lemah. Investor akan berusaha menghindari risiko kebangkrutan yang mungkin terjadi dalam perusahaan sebagai akibat tingginya tingkat leverage yang dimiliki. Rendahnya respon investor akan berdampak pula pada menurunnya nilai ERC perusahaan. Berdasarkan uraian di atas, hipotesis yang dapat dikembangkan adalah :

$\mathrm{H}_{4}$ : Ukuran perusahaan dapat memperkuat pengaruh leverage pada Earning Respon Coefficient

\section{METODE PENELITIAN}

Penelitian ini dilakukan di perusahaan manufaktur yang terdaftar di Bursa Efek Indonesia (BEI) dengan mengakses website www.idx.co.id dan mengunduh data sekunder berupa laporan keuangan perusahaan manufaktur periode 2015-2017. Variabel terikat dalam penelitian ini adalah Earning Response Coefficient (Y). Variabel bebas yang digunakan dalam penelitian ini adalah profitabilitas $\left(\mathrm{X}_{1}\right)$ dan 
Nyoman Sutrisna Dewi dan I ketut Yadnyana. Pengaruh ...

leverage $\left(\mathrm{X}_{2}\right)$. Variabel pemoderasi dalam penelitian ini adalah ukuran perusahaan (Z).

ROA merupakan hasil akhir bersih dari berbagai kebijakan dan keputusan baik keputusan perpajakan maupun pendanaan. Hal ini sejalan dengan proksi yang digunakan oleh Dewi dkk. (2016), Herdirinandasari dan Asyik (2016) dan Ardianti (2018).

$$
\text { ROA }=\frac{\text { Laba Bersih Setelah Pajak }}{\text { Total Aset }} \times 100 \%
$$

Persamaan yang dapat digunakan untuk menentukan DER seperti pada penelitian Dewi dan Putra (2017) serta Mahendra dam Wirama (2017) adalah sebagai berikut :

$$
\text { DER }=\frac{\text { Total Utang }}{\text { Total Ekuitas }}
$$

CAR merupakan proksi harga saham yang menunjukkan besarnya respon pasar terhadap informasi akuntansi yang dipublikasikan dan dihitung dengan menggunakan model pasar yang disesuaikan. Data abnormal return diperoleh dengan harus mencari terlebih dahulu return saham harian dan return pasar harian.

Menghitung return saham harian dan return pasar harian.

$$
\begin{aligned}
& \mathrm{R}_{\mathrm{i} . \mathrm{t}}=\frac{\mathrm{P}_{\mathrm{it}-\mathrm{P}} \mathrm{it}-1_{\mathrm{it}-1}}{\mathrm{P}_{\mathrm{it}}} \\
& \mathrm{R}_{\mathrm{m} \cdot \mathrm{t}}=\frac{\mathrm{IHSG}_{\mathrm{t}}-\mathrm{IHSG}_{\mathrm{t}-1}}{\mathrm{IHSG}_{\mathrm{t}-1}}
\end{aligned}
$$


Keterangan :

$\mathrm{R}_{\mathrm{i} . \mathrm{t}} \quad=$ Return saham perusahaan i pada periode hari ke $\mathrm{t}$

$\mathrm{P}_{\mathrm{it}} \quad=$ Harga penutupan saham perusahaan i pada hari ke $\mathrm{t}$

$\mathrm{P}_{\mathrm{it}-1} \quad=$ Harga penutupan saham perusahaan i pada hari sebelum $\mathrm{t}(\mathrm{t}-1)$

$\mathrm{R}_{\mathrm{m} . \mathrm{t}} \quad=$ Return pasar perusahaan i pada periode hari ke $\mathrm{t}$

$\mathrm{IHSG}_{\mathrm{t}} \quad=$ Indeks Harga Saham Gabungan pada hari ke $\mathrm{t}$

$\mathrm{IHSG}_{\mathrm{t}-1}=$ Indeks Harga Saham Gabungan pada hari $\mathrm{t}-1$

Menghitung Abnormal Return

$$
\mathrm{AR}_{\mathrm{it}}=\mathrm{R}_{\mathrm{i} . \mathrm{t}}-\mathrm{R}_{\mathrm{m} . \mathrm{t}}
$$

Keterangan :

$\mathrm{AR}_{\mathrm{it}} \quad=$ Abnormal return untuk perusahaan i pada hari ke $\mathrm{t}$

$\mathrm{R}_{\mathrm{i} . \mathrm{t}} \quad=$ Return saham perusahaan i pada hari ke $\mathrm{t}$

$\mathrm{R}_{\mathrm{m} . \mathrm{t}} \quad=$ Return pasar perusahaan i pada hari ke $\mathrm{t}$

Menghitung Cummulative Abnormal Return

$$
\mathrm{CAR}_{\text {it }}=\mathrm{CAR}_{(-\mathrm{t}, \mathrm{t})}=\sum_{-\mathrm{t}}^{\mathrm{t}} \mathrm{AR}_{\mathrm{it}}
$$

Keterangan :

$\mathrm{CAR}_{(-\mathrm{t}, \mathrm{t})}=$ Cummulative abnormal return perusahaan $\mathrm{i}$ selama 3 hari sebelum dan 3 hari sesudah laba akuntansi dipublikasikan

$\mathrm{AR}_{\mathrm{it}} \quad=$ Abnormal return untuk perusahaan $\mathrm{i}$ pada hari ke $\mathrm{t}$

Menghitung Unexpected Earning (UE) masing-masing sampel

UE atau laba kejutan adalah selisih antara laba sesungguhnya dengan laba ekspektasian. UE dihitung menggunakan model random-walk seperti yang dilakukan oleh (Collins dan Kothari, 1989).

$$
\mathrm{UE}_{\mathrm{i} . \mathrm{t}}=\frac{\left(\mathrm{AE}_{\mathrm{i} . \mathrm{t}}-\mathrm{AE}_{\mathrm{i}, \mathrm{t}-1}\right)}{\mathrm{AE}_{\mathrm{i}, \mathrm{t}-1}}
$$

Keterangan :

$\mathrm{UE}_{\mathrm{i} . \mathrm{t}} \quad=$ Laba non ekspektasian perusahaan i pada periode $\mathrm{t}$

$\mathrm{AE}_{\mathrm{i} . \mathrm{t}} \quad=$ Laba akuntansi setelah pajak perusahaan i pada tahun $\mathrm{t}$

$\mathrm{AE}_{\mathrm{i} . \mathrm{t}-1}=$ Laba akuntansi setelah pajak perusahaan $\mathrm{i}$ pada tahun $\mathrm{t}-1$ 
ERC merupakan salah satu ukuran yang dapat digunakan untuk mengukur reaksi pasar terhadap informasi laba (Homan, 2018). ERC merupakan koefisien yang diperoleh dari regresi antara proksi harga saham dan laba akuntansi (Chaney dan Jater, 1991). Proksi harga saham yang digunakan adalah CAR, sedangkan proksi laba akuntansi adalah UE. Besarnya koefisien respon laba dihitung dengan persamaan regresi atas data tiap perusahaan sebagai berikut :

$$
\mathrm{CAR}_{\mathrm{i} . \mathrm{t}}=\alpha_{0}+\alpha_{1} \mathrm{UE}_{\mathrm{it}}+\varepsilon
$$

Keterangan :

$\mathrm{CAR}_{\mathrm{i.t}}=$ Cummulative abnormal return perusahaan yang diperoleh dari akumulasi AR pada interval dari hari $\mathrm{t}-3$ hingga hari $\mathrm{t}+3$

$\alpha_{0} \quad=$ Konstanta

$\alpha_{1} \quad=$ Earning Response Coefficient

$\mathrm{UE}_{\mathrm{it}} \quad=$ Unexpected earning perusahaan i pada periode $\mathrm{t}$

$\varepsilon=$ Standar error

Penelitian yang dilakukan Dewi dan Putra (2017), Mahendra dan Wirama (2017), Rahayu dan Suaryana (2015) mengukur size perusahaan dengan rumus sebagai berikut:

$$
\text { Size }=\text { Ln (Total Aset) }
$$

Populasi dalam penelitian ini adalah seluruh perusahaan manufaktur yang terdaftar di Bursa Efek Indonesia periode 2015-2017. Periode 2015-2017 digunakan karena merupakan data terbaru serta untuk melanjutkan penelitian sebelumnya dan sebagai acuan untuk penelitian selanjutnya. Sampel dalam penelitian ini adalah bagian dari perusahaan manufaktur yang terdaftar di Bursa Efek Indonesia periode 2015-2017 yang memenuhi kriteria.

Teknik analisis data dalam penelitian ini dilakukan dengan menggunakan Moderated Regression Analysis (MRA) dengan menggunakan program SPSS 
(Statistical Product and Service Solution). MRA merupakan aplikasi khusus regresi linear berganda yang dalam persamaan regresinya mengandung unsur interaksi (perkalian dua atau lebih variabel independen). Model regresi ini merupakan salah satu cara untuk menguji apakah suatu variabel merupakan variabel moderasi atau tidak. Model persamaan regresi dalam penelitian ini dinyatakan sebagai berikut.

$$
Y=\alpha+\beta_{1} X_{1}+\beta_{2} X_{2}+\beta_{3} Z+\beta_{4} X_{1} Z+\beta_{5} X_{2} Z+\varepsilon
$$

Keterangan:

$\mathrm{Y}=$ Variabel dependen Earning Response Coefficient

$\mathrm{X}_{1} \quad=$ Variabel independen profitabilitas

$\mathrm{X}_{2} \quad=$ Variabel independen leverage

$\mathrm{Z} \quad=$ Ukuran Perusahaan

$\alpha \quad=$ Konstanta

$\beta_{1}-\beta_{5}=$ Koefisien regresi (nilai peningkatan atau pun penurunan)

$\varepsilon \quad=$ Error Term, yaitu tingkat kesalahan penduga dalam penelitian

\section{HASIL DAN PEMBAHASAN}

Statistik deskriptif mendeskripsikan suatu data yang dilihat dari nilai rata-rata (mean), deviasi standar (standard deviation), nilai maksimum dan minimum dari masing-masing variabel. Pengujian statistik deskriptif dimaksudkan untuk memberikan informasi tentang karakteristik proksi dari variabel penelitian dan menganalisa agar sampel yang digunakan dalam penelitian tidak memberikan gambaran kesimpulan yang digeneralisasi. Tabel 2 memperlihatkan hasil statistik deskriptif. 
Tabel 2.

Hasil Statistik Deskriptif

\begin{tabular}{lccccc}
\hline & $\mathrm{N}$ & Minimum & Maksimum & Mean & Std. Deviasi \\
\hline ROA & 174 & 0,0180 & 52,6704 & 7,8644 & 7,3845 \\
DER & 174 & 0,1006 & 4,5469 & 0,8617 & 0,7574 \\
SIZE & 174 & 20,7609 & 32,1510 & 27,6494 & 2,1173 \\
ERC & 174 & $-1,6766$ & 4,6219 & 0,0678 & 0,5953 \\
Valid N & 174 & & & & \\
\hline
\end{tabular}

Sumber: Data diolah, 2018

Variabel ROA yang menggambarkan profitabilitas dengan jumlah 174 sampel memiliki nilai minimum sebesar 0,0180 pada PT. VOKS tahun 2015 dan nilai maksimum sebesar 52,6704 pada PT. MLBI tahun 2017. Nilai rata-rata (mean) dari variabel profitabilitas adalah 7,8644 dimana nilai tersebut mendekati nilai minimum yang artinya tingkat keuntungan yang dihasilkan perusahaan manufaktur yang menjadi sampel penelitian ini masih rendah. Nilai standar deviasi sebesar 7,3845 menunjukkan bahwa terjadi penyimpangan nilai profitabilitas terhadap nilai rata-ratanya sebesar 7,3845.

Variabel DER yang menggambarakan leverage memiliki nilai minimum sebesar 0,1006 pada PT. INCI tahun 2015 dan nilai maksimum sebesar 4,5469 pada PT. INAI tahun 2015. Nilai rata-rata (mean) dari variabel leverage adalah 0,8617 dimana nilai tersebut mendekati nilai minimum yang artinya tingkat utang yang dimiliki perusahaan manufaktur yang menjadi sampel penelitian ini masih rendah. Nilai standar deviasi sebesar 0,7574 menunjukkan bahwa terjadi penyimpangan nilai leverage terhadap nilai rata-ratanya sebesar 0,7574 .

Variabel SIZE yang menggambarkan ukuran perusahaan memiliki nilai minimum sebesar 20,7609 pada PT. DLTA tahun 2015 dan nilai maksimum sebesar 32,1510 pada PT. INDF tahun 2015. Nilai rata-rata (mean) dari variabel ukuran perusahaan adalah 27,6494 dimana nilai tersebut mendekati nilai 
maksimum yang artinya besarnya ukuran perusahaan yang dilihat dari total aset perusahaan manufaktur yang menjadi sampel penelitian ini cukup tinggi. Nilai standar deviasi sebesar 2,1173 menunjukkan bahwa terjadi penyimpangan nilai ukuran perusahaan terhadap nilai rata-ratanya sebesar 2,1173.

Variabel ERC memiliki nilai minimum sebesar -1,6766 pada PT. VOKS tahun 2017 dan nilai maksimum sebesar 4,6219 pada PT. UNVR tahun 2015. Nilai ratarata (mean) dari variabel ukuran perusahaan adalah 0,0678 dimana nilai tersebut mendekati nilai minimum yang artinya tingkat keresponan laba pada perusahaan manufaktur yang menjadi sampel penelitian ini masih rendah. Nilai standar deviasi sebesar 0,5953 menunjukkan bahwa terjadi penyimpangan nilai ERC terhadap nilai rata-ratanya sebesar 0,5953 .

Adapun hasil dari pengujian MRA pada penelitian ini disajikan pada Tabel 3 sebagai berikut.

Tabel 3.

Hasil Uji Moderated Regression Analysis

\begin{tabular}{|c|c|c|c|c|c|c|}
\hline \multirow{3}{*}{\multicolumn{2}{|c|}{ Model }} & \multirow{2}{*}{\multicolumn{2}{|c|}{ Unstandardized Coefficients }} & \multirow{3}{*}{$\begin{array}{l}\text { Standardized } \\
\text { Coefficients } \\
\text { Beta }\end{array}$} & \multirow[b]{3}{*}{ Sig. } & \multirow{3}{*}{$\begin{array}{c}\text { Hasil } \\
\text { Hipotesis }\end{array}$} \\
\hline & & & & & & \\
\hline & & $\mathrm{B}$ & Std. Error & & & \\
\hline & (Constant) & 5,478 & 1,560 & & 0,001 & \\
\hline & ROA & $-0,336$ & 0,089 & $-4,174$ & 0,000 & Ditolak \\
\hline & DER & $-3,795$ & 1,356 & $-4,829$ & 0,006 & Diterima \\
\hline & SIZE & $-0,198$ & 0,056 & $-0,703$ & 0,001 & \\
\hline & ROA*SIZE & 0,012 & 0,003 & 4,405 & 0,000 & Ditolak \\
\hline & DER*SIZE & 0,135 & 0,048 & 4,831 & 0,006 & Diterima \\
\hline
\end{tabular}

Sumber: Data diolah, 2018

Melalui pengujian Moderated Regression Analysis pada Tabel 3 di atas, maka dihasilkan persamaan regresi sebagai berikut.

$$
Y=5,478-0,336 X_{1}-3,795 X_{2}-0,0198 Z+0,012 X_{1} Z+0,135 X_{2} Z
$$


Nilai konstanta 5,478 memiliki arti apabila profitabilitas, leverage, ukuran perusahaan, interaksi antara profitabilitas dan ukuran perusahaan, serta interaksi antara leverage dan ukuran perusahaan bernilai konstan sama dengan nol, maka ERC sebesar 5,478.

Nilai koefisien regresi ROA (profitabilitas) sebesar -0,336 memiliki arti apabila profitabilitas meningkat satu satuan, maka ERC akan menurun sebesar 0,336 dengan asumsi variabel bebas lainnya dianggap konstan.

Nilai koefisien regresi DER (leverage) sebesar $-3,795$ memiliki arti apabila leverage meningkat satu satuan, maka ERC akan menurun sebesar 3,795 dengan asumsi variabel bebas lainnya dianggap konstan.

Nilai koefisien regresi SIZE (ukuran perusahaan) sebesar -0,198 memiliki arti apabila ukuran perusahaan meningkat satu satuan, maka ERC akan menurun sebesar 0,198 dengan asumsi variabel bebas lainnya dianggap konstan.

Nilai koefisien moderat ROA*SIZE sebesar 0,012 mengindikasikan bahwa setiap interaksi dari profitabilitas dan ukuran perusahaan meningkat satu satuan akan mengakibatkan peningkatan pada ERC dengan asumsi variabel bebas lainnya dianggap konstan.

Nilai koefisien moderat DER*SIZE sebesar 0,135 mengindikasikan bahwa setiap interaksi dari leverage dan ukuran perusahaan meningkat satu satuan akan mengakibatkan peningkatan pada ERC dengan asumsi variabel bebas lainnya dianggap konstan.

Adapun hasil dari pengujian koefisien determinasi dalam penelitian ini telah disajikan pada Tabel 4. 
Tabel 4.

Hasil Uji Koefisien Determinasi dan Kelayakan Model

\begin{tabular}{cccc}
\hline Model & $\mathrm{F}$ & Sig & Adjusted $\mathrm{R}$ square \\
\hline 1 & 4,964 & 0,000 & 0,103 \\
\hline Sumber: Data diolah, 2018 & & &
\end{tabular}

Berdasarkan Tabel 4 dapat diketahui nilai dari adjusted $\mathrm{R}$ square adalah 0,103 atau 10,3\%. Ini artinya sebesar 10,3\% Earning Response Coefficient dipengaruhi oleh variabel profitabilitas dan leverage, sedangkan sisanya sebesar 89,7 dijelaskan oleh faktor lain yang tidak dijelaskan dalam model penelitian ini.

Berdasarkan hasil uji kelayakan model pada Tabel 4 di atas, dapat dilihat bahwa nilai signifikansi yakni 0,000 lebih kecil dari $\alpha=0,05$. Hal ini menunjukkan bahwa model yang digunakan dalam penelitian ini layak untuk digunakan sebagai alat analisis untuk menguji pengaruh variabel independen terhadap variabel dependen.

Hipotesis pertama dari penelitian ini adalah untuk mengetahui apakah profitabilitas berpengaruh positif pada Earning Response Coefficient. Berdasarkan hasil pengujian pengaruh profitabilitas $\left(\mathrm{X}_{1}\right)$ pada Earning Response Coefficient (Y) yang ditunjukkan pada Tabel 4.6, diketahui bahwa tingkat signifikansi uji t sebesar 0,000 dimana angka tersebut lebih kecil dari taraf nyata dalam penelitian ini yaitu $\alpha=0,05$ dengan nilai koefisien regresi profitabilitas sebesar $-0,336$. Koefisien penelitian yang berarah negatif mencerminkan hubungan negatif antara profitabilitas dan ERC.

Hasil penelitian ini sejalan dengan penelitian yang dilakukan oleh Anggraini (2015), Pitria (2017) dan Dewi dkk. (2016). Namun hasil penelitian ini bertolak belakang dengan kajian yang ditulis oleh Herdirinandasari dan Asyik (2016) yang menemukan hasil bahwa profitabilitas berpengaruh positif pada ERC. 
Semakin tinggi laba yang dihasilkan perusahaan akan lebih cepat direspon oleh investor dan berpengaruh pada tingginya nilai ERC suatu perusahaan.

Hipotesis kedua dari penelitian ini adalah untuk mengetahui apakah leverage berpengaruh negatif pada Earning Response Coefficient. Berdasarkan hasil pengujian pengaruh leverage $\left(\mathrm{X}_{2}\right)$ pada Earning Response Coefficient $(\mathrm{Y})$ yang ditunjukkan pada Tabel 4.6, diketahui bahwa tingkat signifikansi uji t sebesar 0,006 dimana angka tersebut lebih kecil dari taraf nyata dalam penelitian ini yaitu $\alpha=0,05$ dengan nilai koefisien regresi profitabilitas sebesar $-3,795$. Koefisien penelitian yang berarah negatif mencerminkan hubungan negatif antara leverage dan ERC.

Hasil penelitian ini mendukung penelitian yang dilakukan oleh Nofianti (2014), Dewi dan Putra (2017), Dhaliwal et al. (1991), Moradi et al. (2010), dan An (2015) membuktikan bahwa leverage berpengaruh negatif terhadap ERC. Namun hasil penelitian ini bertolak belakang dengan penelitian yang dilakukan oleh Arif (2016) dan Valipour dan Moradbeygi (2011) yang menyebutkan adanya pengaruh positif antara leverage dan ERC. Tidak selalu penggunaan utang yang tinggi dapat menyebabkan risiko kebangkrutan. Perusahaan yang memiliki tingkat leverage tinggi digunakan untuk menjalankan usaha dengan tujuan agar keuntungan yang diperoleh lebih besar.

Hipotesis ketiga dari penelitian ini adalah untuk mengetahui apakah ukuran perusahaan memperkuat pengaruh profitabilitas pada Earning Response Coefficient. Berdasarkan hasil pengujian yang telah dilakukan sebelumnya pada Tabel 4.6, diketahui bahwa tingkat signifikansi uji t sebesar 0,000 dengan nilai 
koefisien regresi moderasi profitabilitas dengan ukuran perusahaan (ROA*SIZE) sebesar 0,012. Hasil ini menunjukkan bahwa ukuran perusahaan memperlemah pengaruh profitabilitas pada Earning Response Coefficient dan menolak $\mathrm{H}_{3}$.

Perusahaan berukuran besar dianggap mampu untuk meningkatkan kualitas labanya melalui peningkatan kinerja manajemen sehingga investor cenderung lebih percaya pada perusahaan besar. Ukuran perusahaan yang dilihat berdasarkan jumlah aset biasanya mengalami fluktuasi dari tahun ke tahun. Jika pengelolaan aset tidak mampu meningkatkan laba mengingat banyaknya biaya yang dikeluarkan maka dapat menyebabkan penurunan laba sehingga investor tidak akan tertarik untuk berinvestasi. Namun melalui kinerja manajemen yang baik dalam pengelolaan total aset diharapkan perusahaan akan mampu untuk terus memaksimalkan labanya. Kinerja yang baik dari seluruh sumber daya manusia yang dimiliki perusahaan adalah aset terpenting untuk dapat menghasilkan laba. Oleh karena itu komitmen dari seluruh anggota perusahaan sangat dibutuhkan agar laba yang dihasilkan perusahaan meningkat. Komitmen tersebut dapat tercermin dari tidak adanya praktik manajemen laba atau tindakan manipulasi data yang dilakukan oleh perusahaan.

Hipotesis keempat dari penelitian ini adalah untuk mengetahui apakah ukuran perusahaan memperkuat pengaruh leverage pada Earning Response Coefficient. Berdasarkan hasil pengujian yang telah dilakukan sebelumnya pada Tabel 4.6, diketahui bahwa tingkat signifikansi uji t sebesar 0,006 dengan nilai koefisien regresi moderasi leverage dengan ukuran perusahaan (DER*SIZE) 
sebesar 0,135. Hasil ini menerima hipotesis $\mathrm{H}_{4}$ yakni ukuran perusahaan memperkuat pengaruh leverage pada Earning Response Coefficient.

Hasil penelitian ini sejalan dengan teori sinyal dimana informasi laba yang dilaporkan perusahaan merupakan sinyal yang ditujukan pada pasar dengan tujuan pasar akan segera beraksi setelah pengumuman laba dipublikasikan. Untuk mampu menghasilkan laba yang tinggi maka perusahaan besar membutuhkan dana yang lebih banyak. Perusahaan besar dapat menggunakan sumber pendanaan yang berasal dari kreditur untuk menjalankan usahanya sehingga utang yang diperoleh dari kreditur tersebut umumnya berguna untuk memakmurkan pemilik saham dan meningkatkan nilai perusahaan yang tercermin pada harga sahamnya.

\section{SIMPULAN}

Profitabilitas berpengaruh negatif pada Earning Response Coefficient. Perusahaan yang mampu menghasilkan laba yang tinggi belum tentu menjamin bahwa perusahaan memiliki kinerja yang baik. Tingginya tingkat profitabilitas dikhawatirkan atau diduga terjadi praktik manajemen laba atau tindakan manipulasi data. Hal ini menyebabkan respon investor menjadi rendah ketika perusahaan menyampaikan informasi laba sehingga nilai ERC perusahaan turut menjadi rendah.

Leverage berpengaruh negatif pada Earning Response Coefficient. Tingginya tingkat leverage yang dimiliki perusahaan dapat mengakibatkan rendahnya respon investor terhadap pengumuman laba. Investor menjadi kurang percaya dan takut untuk berinvestasi karena perusahaan memiliki tingkat risiko 
kebangkrutan. Rendahnya respon investor terhadap informasi laba yang dilaporkan dapat menyebabkan nilai ERC perusahaan menjadi rendah.

Ukuran perusahaan dapat mempelemah pengaruh profitabilitas pada Earning Response Coefficient. Perusahaan yang berukuran besar biasanya memiliki lebih banyak total aset dan mengeluarkan biaya yang lebih besar dalam menjalankan usaha. Namun apabila biaya pengeluaran yang besar dapat diimbangi dengan peningkatan laba yang dihasilkan perusahaan maka respon investor terhadap pengumuman laba akan menjadi tinggi. Semakin tinggi ukuran perusahaan dan semakin baik perusahaan dalam mengelola aset yang dimiliki untuk tujuan memaksimalkan laba akan berpengaruh pada tingginya nilai ERC pada perusahaan yang bersangkutan.

Ukuran perusahaan dapat memperkuat pengaruh leverage pada Earning Response Coefficient. Perusahaan berukuran besar cenderung membutuhkan dana yang lebih besar pula untuk dapat memaksimalkan labanya melalui peningkatan jumlah produksi. Adanya total aktiva yang besar menyebabkan perusahaan besar lebih mudah dalam meminjam dana kepada kreditur. Namun semakin tinggi tingkat leverage perusahaan mengindikasikan bahwa perusahaan memiliki tingkat keberlangsungan yang lemah sehingga ketika perusahaan melaporkan adanya informasi laba, investor kurang merespon hal tesebut.

Penelitian selanjutnya disarankan menambahkan variabel bebas lain yang diduga memengaruhi Earning Response Coefficient, memperpanjang periode sampel penelitian agar hasil penelitian selanjutnya dapat menunjukkan hasil yang lebih akurat dan menambah sektor perusahaan yang tidak hanya terpaku pada satu 
sektor tertentu, sehingga dapat memperoleh hasil dari penelitian yang dapat digunakan secara lebih luas dan manfaatnya pun akan lebih bernilai bagi banyak pembaca.

Pihak manajemen perusahaan diharapkan untuk lebih memerhatikan relevansi nilai dari informasi laba yang akan disampaikan kepada publik sehingga dapat memberikan penilaian positif masyarakat pada kinerja perusahaan.

\section{REFERENSI}

Adriani, L. (2012). Pengaruh Ukuran Perusahaan dan Struktur Modal terhadap Earnings Response Coefficient (Studi pada Perusahaan Sektor Manufaktur yang Terdaftar di BEI). Skripsi Jurusan Akuntansi Universitas Andalas, Padang.

Agustianto, R. N. (2013). Analisis Faktor-Faktor Yang Berpengaruh Terhadap Perataan Laba (studi empiris pada perusahaan manufaktur yang terdaftar di BEI periode 2011-2013). Skripsi Jurusan Akuntansi Universitas Diponegoro, Semarang.

An, Y. (2015). Earnings Response Coefficients and Default Risk: Case of Korean Firms. International Journal of Financial Research, 6(2), 67-71.

Anggraini, V. (2015). Pengaruh Islamic Social Reporting (ISR), Profitabilitas, dan Leverage Terhadap EarningResponse Coefficient (Studi Empiris Pada Perusahaan yang Terdaftar di Jakarta Islamic Index Tahun 2010-2013). Skripsi Jurusan Akuntansi Universitas Islam Negeri Syarif Hidayatullah, Jakarta.

Ardianti, R. (2018). Pengaruh Alokasi Pajak Antar Periode, Persistensi Laba, Profitabilitas, dan Likuiditas Terhadap Kualitas Laba (Studi Empiris Pada Perusahaan Manufaktur yang Terdaftar di BEI tahun 2012-2016). Jurnal Akuntansi Universitas Sarjanawiyata Tamansiswa, 6(1), 85-102.

Arif, R. N. (2016). Faktor- Faktor yang Mempengaruhi Earning Response Coefficient (ERC) Pada Perusahaan yang Terdaftar di Bursa Efek Indonesia (Periode 2011-2015). Skripsi Jurusan Akuntansi Universitas Islam Negeri Syarif Hidayatullah, Jakarta.

Ball, R. dan Brown, P. (1958). An Empirical Evaluation of Accounting Income Numbers. Journal Of Accounting Research, Autumn, 159-177. 
Cheng, F. F. dan Nasir, A. (2010). Earning Response Coefficients And The Financial Risks Of China Commercial Banks. International Review of Business Research Papers, 6(3), 178-188.

Collins, D. W. dan Kothari, S. P. (1989). An Analysis of Intertemporal and CrossSectional Determinants of Earnings Response Coefficients. Journal of Accounting and Economics 11, 143-181.

Delvira, M. dan Nelvirita. (2013). Pengaruh Risiko Sistematik, Leverage, dan Persistensi Laba Terhadap Earning Response Coefficient (ERC). Jurnal WRA, 1(1), 129-154.

Dewi, A. A. P. K. dan Putra, I. M. P. D. (2017). Pengaruh Leverage Dan Ukuran Perusahaan Pada Earnings Response Coefficient. E-Jurnal Akuntansi Universitas Udayana, 19(1), 367-391.

Dewi, I. G. A. R. P., Yadnyana, I. K., dan Sudana, I. P. (2016). Pengaruh Profitabilitas dan Ukuran Perusahaan Terhadap Ketepatwaktuan Penyampaian Laporan Keuangan dan Implikasinya Pada Earning Response Coefficient. E-Jurnal Akuntansi Universitas Udayana, 5(9), 3031-3056.

Farizky, M. G. (2012). Pengaruh Risiko Kegagalan, Kesempatan Bertumbuh Dan Ukuran Perusahaan Terhadap Earning Response Coefficient Pada Perusahaan Sektor Keuangan Yang Terdaftar Di Bursa Efek Indonesia Tahun 2010-2012. Jurnal Profita Edisi 4, 1-10.

Fitri, L. (2013). Pengaruh Ukuran Perusahaan, Kesempatan Bertumbuh, dan Profitabilitas Terhadap Earnings Response Coefficient (Studi Empiris Pada Perusahaan Manufaktur Yang Terdaftar di Bursa Efek Indonesia (BEI) Tahun 2008-2011). Journal Akutansi Universitas Negeri Padang.

Hasanzade, M., Darabi, R., dan Mahfoozi, G. (2013). Factors Affecting the Earnings Response Coefficient: An Empirical study for Iran. European Online Journal of Natural and Social Sciences, 2(3), 2551-2560.

Hayn, C. (1995). The information content of losses. Journal Accounting and Ecconomics 20, 20, 125-153.

Hejazi, R., Ansari, Z., Sarikhani, M., dan Ebrahimi, F. (2015). The Impact of Earnings Quality and Income Smoothing on the Performance of Companies Listed in Tehran Stock Exchange. International Journal of Business and Social Science, 2(17), 193-197.

Herdirinandasari, S. S., dan Asyik, N. F. (2016). Pengaruh Ukuran Perusahaan, Profitabilitas dan Voluntary Disclousure Terhadap Earning Response 
Coefficient (ERC). Jurnal Ilmu Dan Riset Akuntansi, 5(11), 1-19.

Homan, H. S. (2018). The Effect Of Corporate Social Responsibility Disclosure To Earnings Response Coefficient. International Journal Of Business, Economics and Law, 16(1), 1-8.

Lev, Baruch. (1989). On the Usefulness of Earnings and Earnings Research: Lessons and Directions from Two Decades of Empirical Research. Journal of Accounting Research, (27), hal.153-192.

Mahendra, I. P. Y. dan Wirama, D. G. (2017). Pengaruh Profitabilitas, Struktur Modal, dan Ukuran Perusahaan Pada Earning Response Coefficient. EJurnal Akuntansi Universitas Udayana, 20(3), 2566-2594.

Malahayati, R., Arfan, M., dan Basri, H. (2015). Pengaruh Ukuran Perusahaan dan Financial Leverage terhadap Persistensi Laba dan Dampaknya terhadap Kualitas Laba (Studi pada Perusahaan Manufaktur yang terdaftar di Jakarta Islamic Index). Jurnal Magister Akuntansi Pascasarjana Universitas Syiah Kuala, 4(4), 79-91.

Mashayekhi, B. dan Aghel, Z. L. (2016). A Study on The Determinants of Earnings Response Coefficient in an Emerging Market. World Academy of Science, Engineering, and Technology, 10(7), 2479-2482.

Moradi, M., Salehi, M., dan Erfanian, Z. (2010). A Study of the Effect of Financial Leverage on Earnings Response Coefficient through out Income Approach: Iranian Evidence. International Review of Accounting, Banking, and Finance (IRABF), 2(2), 103-115.

Natalia, D. dan Ratnadi, N. M. D. (2017). Pengaruh Konservatisme Akuntansi Dan Leverage Pada Earnings Response Coefficient. E-Jurnal Akuntansi Universitas Udayana, 20(1), 61-86.

Nofianti, N. (2014). Pengaruh Struktur Modal, Ukuran Perusahaan, dan Kebijakan Deviden Terhadap Koefisien Respon Laba. Jurnal Etikonomi, 13(2), 118147.

Nurdiyah, A. K. (2015). Pengaruh Ukuran Perusahaan, Ukuran KAP, Profitabilitas Dan Leverage Terhadap Earning Response Coefficient (Studi Empiris Pada Perusahaan Manufaktur Yang Terdaftar Di BEI 2011-2013). Skripsi Universitas Muhammadiyah Surakarnata.

Pitria, E. (2017). Pengaruh Kesempatan Bertumbuh, Leverage, Profitabilitas Pada Kualitas Laba (Studi Empiris pada Seluruh Perusahaan yang Terdaftar di BEI Selama Periode 2010-2014). Skripsi Universitas Negeri Padang. 
Rahayu, L. P. A. K. dan Suaryana, I. G. N. A. (2015). Pengaruh ukuran perusahaan dan risiko gagal bayar pada koefisien respon laba. E-Jurnal Akuntansi Universitas Udayana, 13(2), 665-684.

Ross, S. A. (1977). The Determination of Financial Structure: The IncentiveSignalling Approach. The Bell Journal of Economics, 1 (8), hal.23-40.

Rullyan, A. (2017). Pengaruh Default Risk, Profitabilitas dan Risiko Sistematis Terhadap Earning Response Coefficient (Studi Empiris pada Seluruh Perusahaan Yang Terdaftar di BEI tahun 2011-2014). Jurnal Universitas Negeri Padang.

Scott, William R. (2009). Financial Accounting Theory. Edisi ke 5. Toronto: Pearson Prentice Hall.

Setiawati, E., Nursiam, dan Apriliana, F. (2014). Analisis Pengaruh Ukuran, Pertumbuhan Dan Profitabilitas Perusahaan Terhadap Koefisien Respon Laba ( Studi Empiris pada Perusahaan Manufaktur yang terdaftar di Bursa Efek Indonesia ( BEI ) tahun 2009-2011 ). Seminar Nasional Dan Call for Paper (Sancall 2014), 175-188.

Subagyo dan Olivia, C. N. (2012). Faktor-Faktor Yang Mempengaruhi Earnings Response Coefficient. Jurnal Akuntansi, 12(1), 539-558.

Sudarma, I. P. dan Ratnadi, N. M. D. (2015). Pengaruh Voluntary Disclosure Pada Earnings Response Coefficient. E-Jurnal Akuntansi Universitas Udayana, 12(2), 339-357.

Tahir, R. (2016). Corporate Social Responsibility (CSR) And The Implications Of Earning Response Coefficient (ERC). Jurnal Bisnis Preneur Universitas Padjajaran, 1(2), 153-164.

Valipour, H. dan Moradbeygi, M. (2011). Corporate Debt Financing and Earnings Quality. Journal of Applied Finance \& Banking, 1(3), 139-157. 